\title{
Chitra vandijki McCord and Pritchard 2003 - Burmese Narrow-Headed Softshell Turtle
}

\author{
Steven G. Platt ${ }^{1}$, Kalyar Platt ${ }^{2}$, Win Ko Ko ${ }^{1}$, and Thomas R. Rainwater ${ }^{3}$ \\ ${ }^{1}$ Wildlife Conservation Society, Myanmar Program, Aye Yeik Mon 1st Street, Yadanamon Housing Ave., \\ Yangon, Myanmar [sgplatt@gmail.com,winkoko@gmail.com]; \\ ${ }^{2}$ Turtle Survival Alliance, Myanmar Program, Aye Yeik Mon 1st Street, Yadanamon Housing Ave., \\ Yangon, Myanmar [kalyarplatt@gmail.com]; \\ ${ }^{3}$ U.S. Fish and Wildlife Service, Charleston Field Office, 176 Croghan Spur Road, Suite 200, \\ Charleston, South Carolina 29407 USA [trrainwater@gmail.com]
}

Summary.-The Burmese Narrow-headed Softshell Turtle, Chitra vandijki(Family Trionychidae), is a large (carapace length to at least $1000 \mathbf{~ m m}$ ), wholly aquatic turtle endemic to the Ayeyarwady and Chindwin River drainages of Myanmar. Virtually nothing is known concerning the ecology of $C$. vandijki in the wild. Populations are believed to be declining dramatically as a result of widespread over-harvesting to meet the demands of markets in southern China. Establishing a protected area along a suitable stretch of the Ayeyarwady or Chindwin River would greatly benefit $C$. vandijki. Additionally, there is an urgent need to establish captive breeding colonies of $C$. vandijki, but the species has proven difficult to successfully maintain in captivity.

DistRibution. - Myanmar (Burma). Occurs in the Ayeyarwady and Chindwin River drainages and possibly the Sittaung River.

Synonymy. - Chitra burmanica Jaruthanin 2002 (nomen nudum), Chitra vandijki McCord and Pritchard 2003.

SUBSPECIES. - None recognized.

StATUS. - IUCN 2013 Red List: Not Evaluated, TFTSG Draft Red List: Critically Endangered, CR, assessed 2011; CITES: Appendix II, as Chitra spp.

Taxonomy. - The existence of softshell turtles of the genus Chitra in Myanmar (Burma) was long suspected (Smith 1931; van Dijk 1993), but only recently verified (van Dijk 1994; Platt 2001; Platt et al. 2005). Several early workers (Mason 1860; Theobald 1876, 1882; Boulenger
1889; Annandale 1912, Annandale and Shastri 1914) listed Chitra indica as a member of Burma's chelonian fauna, although the basis for its inclusion is unclear. Statements by Theobald (1876) regarding the aggressive disposition of Burmese Chitra seem to imply direct personal experience

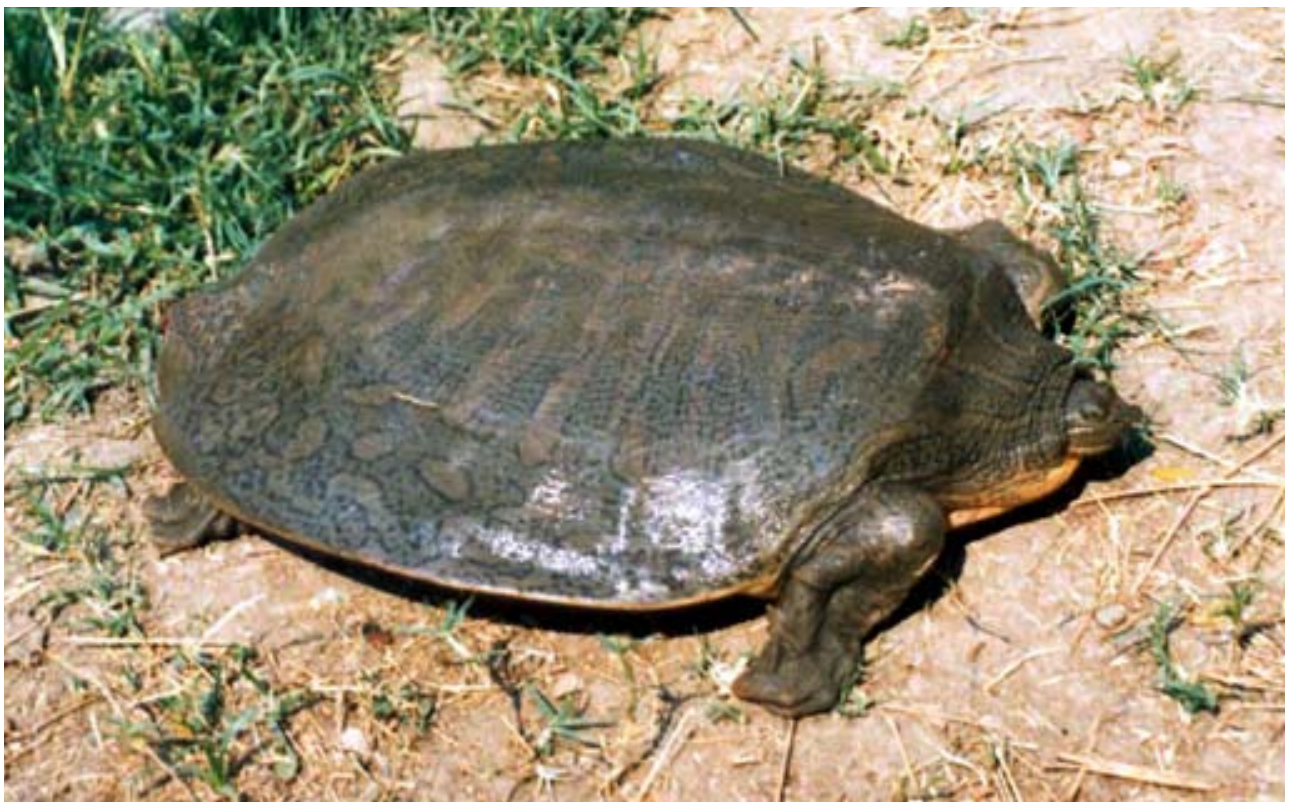

Figure 1. Adult Chitra vandijki from Chindwin River, Myanmar. Photo by Win Ko Ko. 


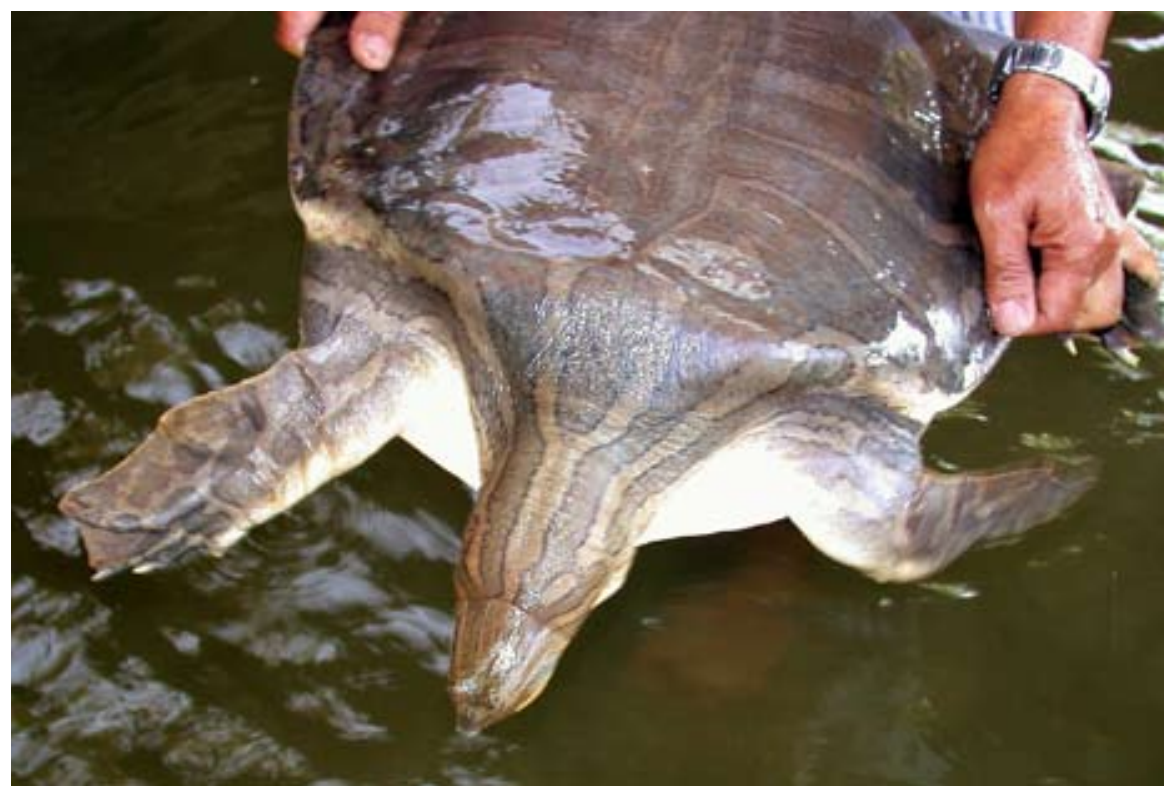

Figure 2. Adult female Chitra vandijki from the Thanlwin River (= Salween River), Myanmar. Photo by Gerald Kuchling.

with the species, but he provided no further information in the account. However, two specimens of Chitra were apparently collected by Theobald in Burma and later deposited in the British Museum of Natural History (van Dijk 1994).

More recently, van Dijk (1994) examined skeletal material from the Mon, Man, and Dokhtawady (Myitnge) Rivers, providing the first verified records of Chitra in Myanmar. Shortly thereafter, Platt (2001) photographed a living Chitra
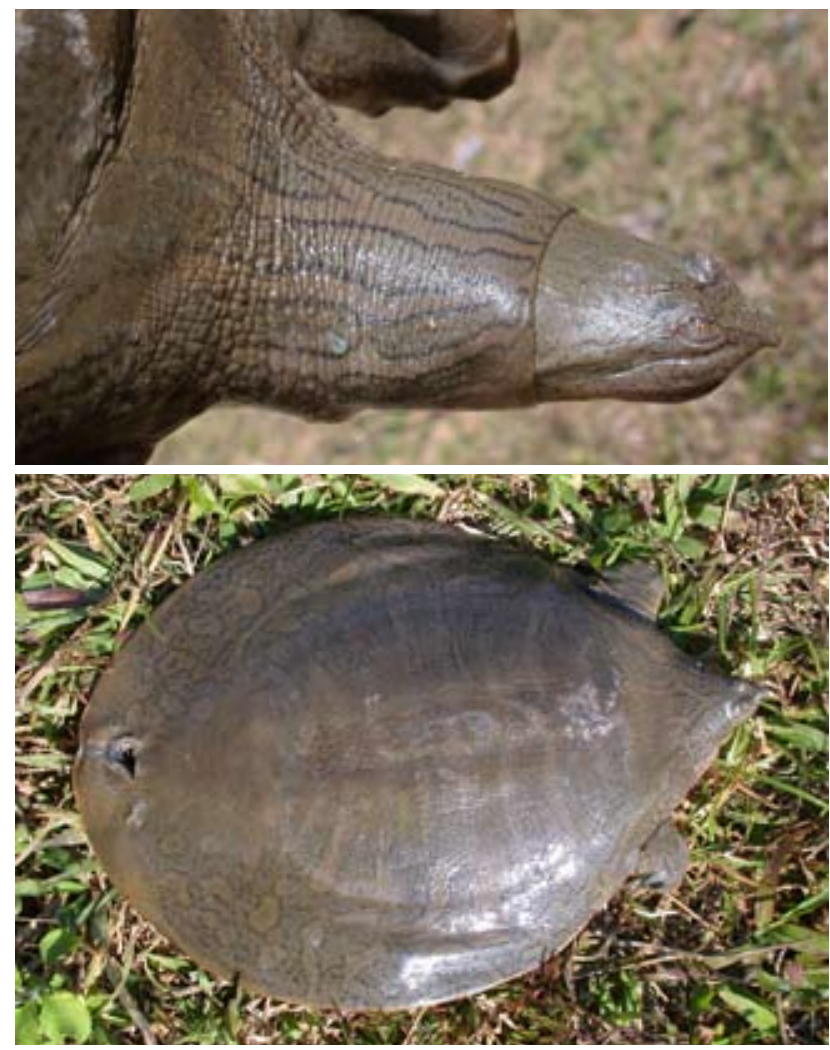

Figure 3. Juvenile Chitra vandijki from Na Maine Taung, upper Chindwin River, Myanmar. Photo by Gerald Kuchling. at Myinthar-Kyarnyut Village along the Ayeyarwady River. The specimen was reportedly taken by fishermen a short distance upstream at Khayansat Kone Village. Additional specimens of Chitra, almost certainly originating from Myanmar were obtained from wildlife markets in Ruili, Yunnan Province, China (Engstrom et al. 2002; McCord and Pritchard 2003). Analysis of mitochondrial DNA from these market specimens indicated that Chitra from Myanmar constitutes a distinct lineage from other Asian Chitra (Engstrom et al.2002; Engstrom and McCord 2003), leading McCord and Pritchard (2003) to describe them as Chitra vandijki on the basis of zoogeography, molecular data, and morphology. The specific epithet is a patronym honoring Dr. Peter Paul van Dijk for his contributions to chelonian biology and conservation (McCord and Pritchard 2003). Chitra burmanica as proposed by Jaruthanin (2002 as cited by McCord et al. 2003) is considered invalid because the name fails to comply with at least five articles of the International Code of Zoological Nomenclature (McCord et al. 2003). Chitra from Myanmar have been variously placed

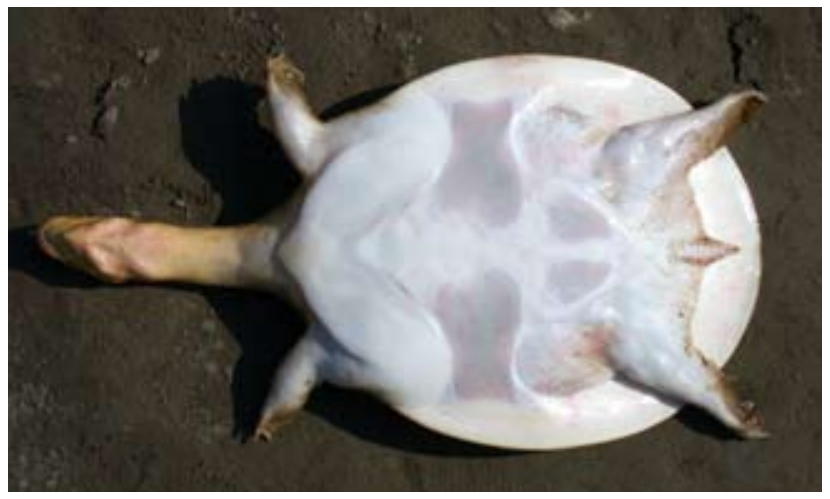

Figure 4. Juvenile Chitra vandijki from Aung Tha, upper Chindwin River, Myanmar. Photo by Gerald Kuchling. 


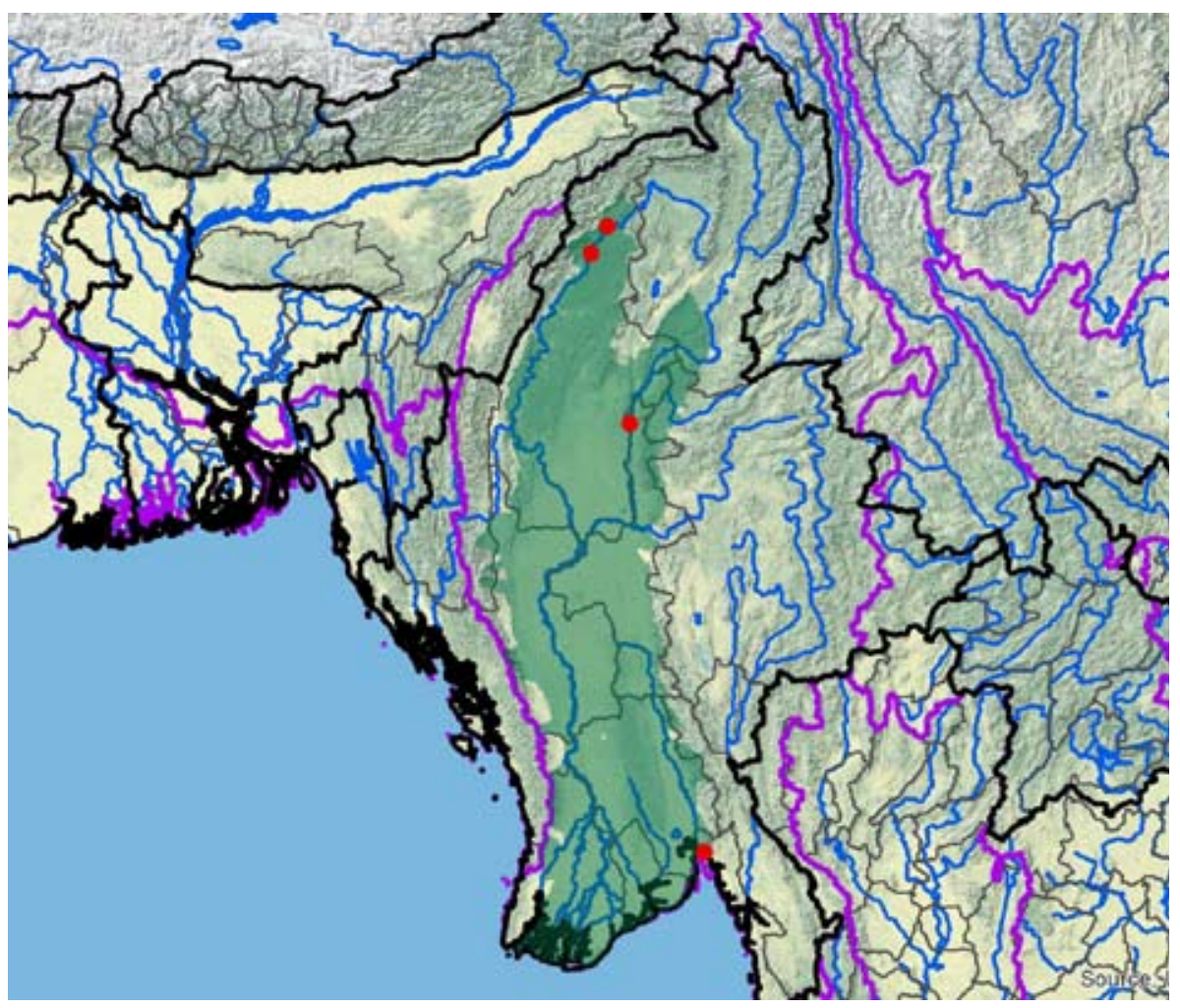

Figure 5. Distribution of Chitra vandijki in Myanmar in southern Asia. Purple lines = boundaries delimiting major watersheds (level 3 hydrologic unit compartments - HUCs); red dots = museum and literature occurrence records of native populations based on recent and authors' data; green shading = projected native distribution based on GIS-defined HUCs constructed around verified localities and then adding HUCs that connect known point localities in the same watershed or physiographic region, and similar habitats and elevations as verified HUCs (Buhlmann et al. 2009), and adjusted based on authors' subsequent data.

in five different genera (Chitra, Gymnopus, Pelochelys, Testudo, and Trionyx); a detailed chresonymy is presented in McCord and Pritchard (2003).

Because Chitra lacks the ability to disperse across oceanic barriers, genetic isolation of the three Chitra species is essentially complete (McCord and Pritchard 2003; Engstrom and McCord 2003). Molecular data indicate Chitra comprises a monophyletic clade (Engstrom et al. 2004), and that $C$. vandijki is genetically more similar to $C$. chitra than $C$. indica (Engstrom et al. 2002; Engstrom and McCord 2003). Phenotypically, however, $C$. vandijki more closely resembles $C$. indica and is included in the $C$. indica phenotypic group (McCord and Pritchard 2003). The apparent discrepancy between molecular results and phenotypic grouping is explained by past isolating events; $C$. vandijki and $C$. chitra became isolated from a $C$. indica ancestor, only to later become isolated from each other (McCord and Pritchard 2003). There are no currently recognized subspecies of $C$. vandijki.

Chitra vandijki is known by a variety of local names in Myanmar (Kuchling et al. 2004; Platt et al. 2013), including kabhar leik, a name also applied to Amyda cartilaginea and Nilssonia formosa (Platt et al. 2004). Kabhar leik literally translates to "Earth turtle" and refers to the local belief that large softshell turtles are extremely long-lived, i.e., as "old as the Earth". Chitra vandijki is more commonly known as zying kyar leik ("striped turtle") in reference to the distinctive, striped carapacial pattern that distinguishes it from other large softshell turtles in Myanmar. Other Burmese names for $C$. vandijki are likewise descriptive and include: (1) guang thay leik ("small-headed turtle"); (2) me gyaung yin leik ("crocodile turtle" because the head shape is thought to resemble that of a crocodile); (3) kha yu leik ("snail turtle" owing to the similarity of the carapacial pattern to the coloration of freshwater snail shells); (4) thee leik ("sand turtle" due to its habit of burrowing into sandy river bottoms); (5) leik ngan ("goose-neck turtle", a reference to its long neck); and (6) Shan gyi leik maung ("large Shan arm turtle", a somewhat oblique reference to the coloration of the skin which resembles tattoos worn on the biceps of Shan men).

Description. - Chitra vandijki is a large softshell turtle in the Chitra indica phenotypic group (McCord and Pritchard 2003), and distinguished from the latter by having (1) a wider bony shell and neural bones; (2) ribs extending beyond the bony carapace; (3) no midline carapacial stripe; (4) a distinct third pair of neck stripes; (5) ocelli near the eyes; and (6) black speckling on the chin (McCord and Pritchard 2003).

Because so few specimens of $C$. vandijki are available for study, size maxima have yet to be established; however, based on the size of congeners, large adults probably attain a leathery carapace length (sensu Pritchard 2001) of > 1000 
$\mathrm{mm}$ and body mass of $>100 \mathrm{~kg}$ (Annandale and Shastri 1914; Smith 1931; Minton 1966; Cox et al. 1998; Pritchard 2001).

The dark leathery carapace of $C$.vandijki is characterized by chocolate-brown and yellow-ochre markings, and lacks a distinct midline stripe. The dark streaks over the costal bones are noticeably asymmetrical in most individuals. The leathery peripheral region of the dorsal disk is covered by light blotches interspersed with less distinct darker speckling. Ontogenetic change in dorsal pigmentation is likely, but remains undescribed owing to the lack of large specimens. The plastron is white to pinkish white, and the tail is short and stubby.

The short proboscis gives the head an elongate, blunt appearance, and the head and neck are characterized by seven distinct black-edged longitudinal, often asymmetrical stripes with a V-shaped mark commencing anterior to the disk margin. One to two pairs of distinct ocelli are located behind or between the eyes. The iris is bright golden-yellow and the chin is speckled with black. The forelimbs of $C$. vandijki bear three to four sharp-edged lamellae, in addition to round-edged pseudodigits that function to deploy the digital webbing.

Sexual size dimorphism has not been described in $C$. vandijki. However, in the sister taxon $C$. chitra, females are larger than males (Pritchard 2001). Male $C$. indica have relatively longer and thicker tails than females (Ernst and Barbour 1989), and the same is likely true for $C$. vandijki. Hatchling $C$. vandijki have yet to be described.

Distribution. - Chitra vandijki is endemic to Myanmar and confirmed records are available only for the Ayeyarwady and Chindwin Rivers, and their tributaries. Only a small number of specimens are known and of these, specific locality data are available for three. The type locality is Khayansat Kone Village (23⒗30’N; 9558.99’E), along the Ayeyarwady River, upstream from Mandalay where Platt et al. (2005) examined a living $C$. vandijki in 2001. Kuchling et al. (2004) obtained two additional specimens from Aung Tha (2600'79'”N; 95³9'69'”E) and Na Maine Taung $\left(25^{\circ} 38^{\prime} 19^{\prime \prime} \mathrm{N}\right.$; 95 $\left.25^{\circ} 71^{\prime \prime} \mathrm{E}\right)$ villages along the upper Chindwin River. Van Dijk (1994) examined skeletal material said to be from the Mon, Man, and Dokhtawady (Mytinge) Rivers, all tributaries of the Ayeyarwady. Additionally, Platt and Kalyar (2004) noted two adult $C$. vandijki (CL ca. $600-700 \mathrm{~mm}$ ) in a pond at Kyaik Paw Law Pagoda in Kyaikto $\left(17^{\circ} 18.17^{\prime} \mathrm{N}\right.$; $\left.97^{\circ} 00.88^{\prime} \mathrm{E}\right)$, a town near the mouth of the Sittaung River. Because turtles and fish that are released in pagoda ponds are generally obtained locally and seldom transported over great distances, this observation raises the possibility that $C$. vandijki also occurs in the Sittaung River system. Although their specific provenance cannot be determined, other $C$. vandijki obtained from markets in southern China
(McCord and Pritchard 2003) were undoubtedly collected in Myanmar.

Habitat and Ecology. - Chitra vandijki inhabits medium to large lowland rivers with sandbanks suitable for nesting. This species is almost wholly aquatic and like $C$. indica, probably capable of pharyngeal respiration allowing for prolonged submergence (Minton 1966). Captives remain underwater and buried beneath the substrate (W.P. McCord, in litt.), and adults are said to be aggressive and capable of inflicting a severe bite; otherwise little is known concerning behavior (Theobald 1876; Smith 1931; Ernst and Barbour 1989).

Virtually nothing is known about the ecology of $C$. vandijki in the wild. Congeners reportedly consume fish, molluscs, crabs, shrimp, and aquatic plants (Smith 1931; Nutaphand 1979). In captivity Chitra is adept at ambushing fish from a position of concealment. Turtles remain buried in sand with only the eyes and nostrils exposed and capture passing fish with an extremely rapid forward movement of the head (Pritchard 2001).

Reproduction has not been studied in C. vandijki, but other Chitra deposit large clutches (ca. 80 to 100 eggs) of spherical white eggs with tough, leathery shells (Nutaphand 1979; Ernst and Barbour 1989; Pritchard 2001). Nesting in $C$. vandijki probably occurs early in the dry season (November - December) when suitable oviposition sites become exposed by receding water levels. Chitra vandijki occurs sympatrically with Amyda cartilaginea and Nilssonia formosa in the Ayeyarwady and Chindwin Rivers (Platt 2001; Kuchling et al. 2004; Platt et al. 2005). Pritchard (2001) suggested that sympatric trionychids avoid competition by utilizing different microhabitats and feeding niches within the same general area. However, niche partitioning among sympatric softshell turtles in Myanmar has not been investigated.

Population Status. - Few field records and little population data are currently available for $C$. vandijki making conclusions regarding current trends somewhat speculative. However, given the dense human population and intense fishing pressure along the major rivers of Myanmar, as well as the probable demise of other large, sympatric trionychid turtles (Platt et al. 2000, Kuchling et al. 2004; Platt et al. $2004,2005)$, it is most likely that $C$. vandijki populations are declining throughout the species' limited range. Indeed, the fishermen we interviewed along the Ayeyarwady River considered $C$. vandijki rare and generally catch only about one per year (Platt et al. 2005). Likewise, van Dijk (1994) noted that villagers regarded C.vandijki as "rare to very rare" with only a few being caught each year along the Mon River. In contrast, interviews conducted by Kuchling et al. (2004) suggest that populations in the upper Chindwin and Nan Tha Let rivers may be less impacted by harvesting than elsewhere in Myanmar.Individual fishermen along these rivers reported 
catching 20-25 C. vandijki every season (Kuchling et al. 2004). Tellingly, most of the $C$. vandijki specimens now available for study were obtained from wildlife markets in southern China (Engstrom et al. 2002; McCord and Pritchard 2003). Owing to the rampant, unregulated harvest of turtles throughout Myanmar, we concur with the recent preliminary status assessment by the IUCN/SSC Tortoise and Freshwater Turtle Specialist Group (Turtle Conservation Coalition 2011) and regard $C$. vandijki as Critically Endangered.

Threats to Survival. - Softshell turtles have long been exploited by rural Burmese fishermen for food (Platt et al. 2000). Interviews with fishermen and observations along the Ayeyarwady and Chindwin Rivers (Thorbjarnarson et al. 2000; Platt 2001; Kuchling et al. 2004; Platt et al. 2004, 2005) have indicated that softshell turtles are taken using fishing nets, bamboo fish traps, unbaited and baited setlines, and harpoons. Cut fish and occasionally leeches are used to bait hooks on setlines, while at other times arrays of unbaited hooks are strung in shallow water in hopes of snagging a passing turtle. While these observations pertain largely to $N$. formosa and A. cartilaginea, these techniques certainly capture $C$. vandijki as well. The specimen we examined at Khayansat Village was taken on an unbaited hook set in shallow water along the shore (Platt et al. 2005). Where turbidity is low, divers search the river bottom and harpoon turtles buried in the substrate. Kuchling et al. (2004) noted that a few turtles are taken with explosives or poisons. Villagers also collect softshell turtle eggs from riverside sandbanks during December - March (Platt 2001; Platt et al. 2005, 2013).

Historically the take of softshell turtles was primarily a subsistence harvest; turtles were consumed by fishermen or sold at local markets and a few were released in Buddhist temple ponds (Annandale 1914; Plattet al. 2004). However, this situation changed abruptly in the mid-1990s when traders began visiting riverside communities to purchase living turtles for export over well-established trade routes (Outram and Fane 1940) into southern China (Platt et al. $2000,2004,2005)$. This period coincided with a dramatic increase in the harvest of wild chelonians throughout Southeast Asia to supply burgeoning Chinese wildlife markets (Jenkins 1995; Compton 2000; van Dijk et al. 2000), where an especially high demand for softshell turtles exists (Lau and Shi 2000). In addition to chronic over-harvesting, fishermen on the upper Chindwin attributed population declines of $C$. vandijki to gold mining activities, the use of explosives and poisons for fishing, and egg collection by villagers (Kuchling et al. 2004). Furthermore, most sandbanks suitable for turtle nesting are now occupied by villagers (Kuchling et al. 2004). The domestic pigs and dogs of these villagers pose a further threat to population recruitment (Kuchling et al. 2004). Finally, the habitat degradation evident along some reaches of the Ayeyarwady and Chindwin rivers likely has a detrimental impact on populations of softshell turtles (Platt 2001). Nonetheless, we regard commercial over-harvesting to meet the demands of Chinese wildlife markets as the single greatest threat to the continued survival of $C$. vandijki.

Conservation Measures Taken. - While the subsistence harvest of $C$. vandijki and other chelonians is permitted in Myanmar, commercial harvesting is illegal under domestic forestry and fisheries legislation (Platt et al.2000). Protective legislation is enforced by the Fisheries Department and the Wildlife Conservation Division of the Forest Department. The former does not issue permits for commercial harvesting of turtles and Law 34 provides stiff penalties for those engaged in turtle trading. However, enforcement of existing legislation is often lax and appears largely ineffectual in curbing the illegal flow of chelonians from Myanmar into southern China. Because C. vandijki is listed under Appendix II of CITES (Proposal 12.31 adopted at the 12th Conference of Parties, Santiago, Chile, 3-15 November 2002), this trade is also in clear violation of the convention, which Myanmar signed on 13 June 1997 (Platt et al. 2000).

All wildlife is afforded complete protection in the Wildlife Sanctuaries and National Parks of Myanmar (Platt et al.2000), but unfortunately $C$. vandijki has not been reported to occur in any protected area. Chitra vandijki is difficult to maintain in captivity (see Captive Husbandry below) and we are unaware of any successful captive breeding programs. Although C. vandijki was described (McCord and Pritchard 2003) after the most recent IUCN Red List assessments in 2000, Myanmar populations of $C$. indica are listed as Endangered (IUCN/SSC Tortoise and Freshwater Turtle Specialist Group and Asian Turtle Trade Working Group 2000). A preliminary assessment conducted by the IUCN/ SSC Tortoise and Freshwater Turtle Specialist Group in 2011 suggested the conservation status of $C$. vandijki should be changed to Critically Endangered based on IUCN criteria (Turtle Conservation Coalition 2011).

Conservation Measures Proposed. - Based on current levels of exploitation in Myanmar, the seemingly insatiable demands for softshell turtles by Chinese wildlife markets, and its restricted distribution, we concur with Engstrom et al. (2002) and the 2011 TFTSG draft Red List assessment, and strongly recommend that $C$. vandijki be assessed as Critically Endangered on future editions of the IUCN Red List.

A protected area encompassing a suitable stretch of the Ayeyarwady or Chindwin Rivers would prove invaluable for the conservation of large softshells, including C.vandijki, as well as other endangered riverine fauna (e.g., the Irrawaddy Dolphin, Orcaella brevirostris; Smith et al. 1997). Additional surveys are warranted along the major rivers of Myanmar to determine the current status and distribution of C. vandijki, 
and perhaps locate populations that would prove amenable to in-situ conservation efforts. Moreover, there is an urgent need to establish captive breeding colonies of $C$. vandijki, both within Myanmar and elsewhere. Finally, and most importantly, it is imperative for Myanmar and Chinese authorities to curb the trans-border wildlife trade between the two countries.

Captive Husbandry. - While other Chitra are successfully farmed in Thailand and Malaysia (Gurley 2003), C. vandijki suffers high mortality during transit and in captivity (McCord and Pritchard 2003). Consequently, C. vandijki remains poorly represented among captive collections and to our knowledge has yet to successfully reproduce in captivity. Like its congeners, $C$. vandijki is best maintained under a natural light cycle in 25 to $40 \mathrm{~cm}$ of cool ( 21 to $26^{\circ} \mathrm{C}$ ) water over a substrate of fine sand approximately $25 \mathrm{~cm}$ deep (W.P. McCord, in litt.). Captives will remain completely buried beneath the sand for extended periods. McCord (in litt.) recommends inoculating the enclosure with natural pond microflora. Chitra vandijki will take appropriate sized living fish offered once or twice weekly.

Current Research. - Other than limited surveys conducted in conjunction with other fieldwork (Win Ko Ko 2006a, 2006b; Platt et al. 2013), there are no research projects involving $C$. vandijki underway at this time.

Acknowledgments. - We thank Peter Paul van Dijk and John Iverson for supplying critical references, Gerald Kuchling for providing photographs and references, and William P. McCord for sharing his knowledge of captive husbandry. An early draft of this account was improved by the comments of Tom Stryker, Ruben Cogburn, Jacob McCandles, Anders Rhodin, and Raymond Saumure. Lewis Medlock is thanked for assistance with various field projects. The findings and conclusions in this article are those of the authors and do not necessarily represent the views of the U.S. Fish and Wildlife Service.

\section{LITERATURE CITED}

AnNANDALE, N. 1912.The Indian mud-turtles(Trionychidae). Records of the Indian Museum 7:151-180.

Annandale, N. And Shastri, M.H. 1914. Relics of the worship of mud-turtles (Trionychidae) in India and Burma. Journal of the Asiatic Society of Bengal 10:131-138.

Boulenger, G.A. 1889. Catalogue of the Chelonians, Rhynchocephalians and Crocodiles in the British Museum (Natural History). London: Taylor and Francis, 312 pp.

Buhlmann, K.A., Akre, T.S.B., Iverson, J.B., Karapatakis, D., MitTERMEIER, R.A., GeOrges, A., Rhodin, A.G.J., vAN DiJK, P.P., AND GibBons, J.W. 2009. A global analysis of tortoise and freshwater turtle distributions with identification of priority conservation areas. Chelonian Conservation and Biology 8(2):116-149.

Compton, J.2000. An overview of Asian turtle trade. In: van Dijk, P.P., Stuart,B.L., and Rhodin,A.G.J.(Eds.).Asian Turtle Trade:Proceedings of a Workshop on Conservation and Trade of FreshwaterTurtles and Tortoises in Asia. Chelonian Research Monographs 2:24-29.

Cox, M.J., van DiJK, P.P., NABHITABHATA, J., AND ThIRAKHUPT, K. 1998. A Photographic Guide to Snakes and Other Reptiles of Peninsular Malaysia, Singapore, and Thailand. London: New Holland Publishers, $144 \mathrm{pp}$.

Engstrom, T.N. AND McCoRD, W.P. 2003. Molecular support for taxonomic conclusions of McCord and Pritchard (2002), regarding Chitra. Hamadryad 27(1)(2002)[2003]:57-61.

ENGSTROM,T.N.,ShafFer,H.B., ANDMcCoRd,W.P.2002.Phylogenetic diversity of endangered and critically endangered southeast Asian softshell turtles (Trionychidae: Chitra). Biological Conservation 104:173-179.

Engstrom, T.N., Shaffer, H.B., AND McCoRd, W.P. 2004. Multiple data sets, high homoplasy, and the phylogeny of softshell turtles (Testudines: Trionychidae). Systematic Biology 53:693-710.

ERnST, C.H. AND BARBOUR, R.W. 1989. Turtles of the World. Washington, DC: Smithsonian Institution Press, 313 pp.

GurLEY,R. 2003. Keeping and Breeding FreshwaterTurtles. Montreal: Living Art Publishing, 297 pp.

IUCN/SSC Tortoise and Freshwater Turtle Specialist Group, and Asian Turtle Trade Working Group. 2000. Recommended changes to 1996 IUCN Red List Status of Asian Turtle Species. In: van Dijk, P.P., Stuart, B.L., and Rhodin, A.G.J.(Eds.). Asian Turtle Trade: Proceedings of a Workshop on Conservation and Trade of Freshwater Turtles and Tortoises in Asia. Chelonian Research Monographs 2:156-164.

JENKINS, M.D. 1995. Tortoises and Freshwater Turtles: The Trade in Southeast Asia. Cambridge, UK: TRAFFIC International, 48 pp.

Kuchling, G., Win KoKo, Tint Lwin, SeinAung Min, Khin Myo Myo, ThinThinKhaing(II),WinWinMar,And ThinThinKhaing(I). 2004. The softshell turtles and their exploitation at the upper Chindwin River, Myanmar: range extensions for Amyda cartilaginea, Chitra vandijki, and Nilssonia formosa. Salamandra 40:281-296.

LAU, M. AND SHI, H. 2000. Conservation and trade of terrestrial and freshwater turtles and tortoises in the Peoples Republic of China. In: van Dijk, P.P., Stuart, B.L., and Rhodin, A.G.J. (Eds.). Asian Turtle Trade:Proceedings of a Workshopon Conservation and Trade of Freshwater Turtles and Tortoises in Asia. Chelonian Research Monographs 2:30-38.

Mason, F. 1860. Burmah, its People and Natural Productions; or Notes on the Nations, Fauna, Flora, and Minerals of Tenasserim,Pegu and Burmah. London: Thomas, Stowe, and Ranney, 914 pp.

McCord, W.P. AND PRITChaRd, P.C.H. 2003. A review of the softshell turtles of the genus Chitra, with the description of new taxa from Myanmar and Indonesia (Java). Hamadryad 27(1)(2002) [2003]:11-56.

McCord, W.P., Pauwels, O.S.G., Bour, R., Cherot, F., Iverson, J.B., PritchaRd,P.C.H.,ThiRAKHUPt,K.,KITIMASAK,W., ANDBUndHITWONGRUT,T.2003.Chitraburmanica sensu Jaruthanin,2002(Testudines: Trionychidae): an unavailable name. Hamadryad 27:214-216.

Minton, S.A., JR. 1966. A contribution to the herpetology of West Pakistan. Bulletin of the American Museum Natural History 134:27-184.

NutAPHAND, W. 1979. The Turtles of Thailand. Bangkok: Siamfarm Zoological Gardens, 222 pp.

Outram, F. AND Fane, G.E. 1940. Burma Road, back door to China. National Geographic 77(11):629-658.

Platt, S.G. 2001. An investigation into the conservation status of Kachuga trivittata and other turtles of the upper Ayeyarwady and Dokhtawady (Myitnge) Rivers, Myanmar. Report to Wildlife Conservation Society, Bronx, New York, 46 pp.

Platt, S.G. and Kalyar. 2004. An investigation into the conservation status of turtles at Inle Lake and other sites in eastern Myanmar. 
Report to Wildlife Conservation Society, Bronx, New York, 6 pp.

Platt, S.G., Win Ko Ko, and Kalyar. 2000. Exploitation and conservation status of tortoises and freshwater turtles in Myanmar. In: van Dijk, P.P., Stuart, B.L., and Rhodin, A.G.J.(Eds.). Asian Turtle Trade: Proceedings of a Workshop on Conservation and Trade of Freshwater Turtles and Tortoises in Asia. Chelonian Research Monographs 2:95-100.

Platt, S.G., Kalyar, and Rainwater, T.R. 2004. Inle Lake Turtles, Myanmar with notes on Intha and $\mathrm{Pa}-\mathrm{O}$ ethnoherpetology. Hamadryad 29:5-14.

Platt, S.G., Win Ko Ko, Lay Lay Khaing, Khin Myo Myo, Tint Lwin,ThandaSwe,Kalyar,andRainwater, T.R.2005. Noteworthy records and exploitation of selected chelonians from the Ayeyarwady, Chindwin, and Dokhtawady Rivers, Myanmar. Chelonian Conservation and Biology 4:942-948.

Platt, S.G., Platt, K., and Khin Myo Myo. 2013. An expedition to central and western Myanmar: Minzontaung Wildlife Sanctuary, upper Chindwin River, and Naga Hills. Report to Wildlife Conservation Society, Bronx, New York, 76 pp.

PritchaRD, P.C.H. 2001. Observations on body size, sympatry, and niche divergence in softshell turtles (Trionychidae). Chelonian Conservation and Biology 4:5-27.

Smith, B.D., Hpone Thant, J. Min Lwin, and Shaw, C.D. 1997. Investigation of cetaceans in the Ayeyarwady River and northern coastal waters of Myanmar. Asian Marine Biology 14:173-194.

Sмrтн, M.A. 1931. The Fauna of British India, including Ceylon and Burma.ReptiliaandAmphibia.Vol.1.Loricata,Testudines.London: Taylor and Francis, Ltd., 185 pp.

Theobald, W. 1876. Descriptive Catalogue of the Reptiles of British India. London: Thacher, Spink, and Co., 238 pp.

THEOBALD, W. 1882. Burma,its People and Productions or, Notes on the Fauna, Flora, and Minerals of Tenasserim,Pegu, and Burma. Vol.1. Geology, Mineralogy, and Zoology. Hertford: S. Austin Publ.

Thorbjarnarson, J., Platt, S.G., and Saw Tun Khaing. 2000. Conservation status of freshwater turtles in Meinmahla Kyun Wildlife Sanctuary and vicinity, Myanmar. Natural History Bulletin of the Siam Society 48:185-191.

Turtle Conservation Coalttion[Rhodin,A.G.J.,WAlde,A.D.,Horne, B.D., van DiJK, P.P., Blanck, T., and Hudson, R. (Eds.)]. 2011.
Turtles in Trouble: The World's 25+MostEndangered Tortoises and Freshwater Turtles-2011. Lunenburg, MA: IUCN/SSC Tortoise and Freshwater Turtle Specialist Group, Turtle Conservation Fund, Turtle Survival Alliance, Turtle Conservancy, Chelonian Research Foundation, Conservation International, Wildlife Conservation Society, and San Diego Zoo Global, 54 pp.

vANDIJK,P.P. 1993. Myanmarturtles: Reporton a preliminary survey of the Testudines of the Ayeyarwady Basin. Report to Turtle Recovery Program, The World Conservation Union-IUCN/SSC Tortoise and Freshwater Turtle Specialist Group, 34 pp.

VAN DIJK, P.P. 1994. Report on a visit to Myanmar, 18-28 January 1994. Report to Turtle Recovery Program, The World Conservation Union-IUCN/SSC Tortoise and Freshwater Turtle Specialist Group, 23 pp.

van DiJK, P.P., Stuart, B.L., And Rhodin, A.G.J. (Eds.). 2000. Asian Turtle Trade: Proceedings of aWorkshop on Conservation and Trade of Freshwater Turtles and Tortoises in Asia. Chelonian Research Monographs No. 2, 164 pp.

WinKoKo,KhinMyoMyo,AND Kyaw Moe.2006a.Turtle conservation and public education program in upper Chindwin River (December 2005 to February 2006). Report to Wildlife Conservation Society Myanmar Program, Yangon, Myanmar, 27 pp.

Win Ko Ko, Khin Myo Myo, and Kyaw Moe. 2006b. Final report of freshwaterturtleconservation toaChindwin Riversegment between Htamanthi Village and Khamti, and Mandalay Yadanabon Zoo (September 2005 to August 2006). Report to Wildlife Conservation Society Myanmar Program, Yangon, Myanmar, 31 pp.

\section{Citation Format for this Account:}

Platt, S.G., Platt, K., Win Ko Ko, and Rainwater, T.R. 2014. Chitra vandijki McCord and Pritchard 2003 - Burmese NarrowHeaded Softshell Turtle. In: Rhodin, A.G.J., Pritchard, P.C.H., van Dijk, P.P., Saumure, R.A., Buhlmann, K.A., Iverson, J.B., and Mittermeier, R.A. (Eds.). Conservation Biology of Freshwater Turtles and Tortoises: A Compilation Project of the IUCN/SSC Tortoise and Freshwater Turtle Specialist Group. Chelonian Research Monographs No.5,pp.074.1-7, doi:10.3854/ crm.5.074.vandijki.v1.2014, http://www.iucn-tftsg.org/cbftt/. 